\title{
The 20 February 2010 Madeira flash-floods: synoptic analysis and extreme rainfall assessment
}

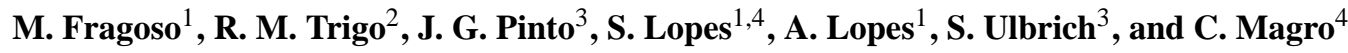 \\ ${ }^{1}$ IGOT, University of Lisbon, Portugal \\ ${ }^{2}$ IDL, Faculty of Sciences, University of Lisbon, Portugal \\ ${ }^{3}$ Institute for Geophysics and Meteorology, University of Cologne, Germany \\ ${ }^{4}$ Laboratório Regional de Engenharia Civil, R.A. Madeira, Portugal \\ Correspondence to: M. Fragoso (mfragoso@campus.ul.pt)
}

Received: 9 May 2011 - Revised: 26 September 2011 - Accepted: 31 January 2012 - Published: 23 March 2012

\begin{abstract}
This study aims to characterise the rainfall exceptionality and the meteorological context of the 20 February 2010 flash-floods in Madeira (Portugal). Daily and hourly precipitation records from the available rain-gauge station networks are evaluated in order to reconstitute the temporal evolution of the rainstorm, as its geographic incidence, contributing to understand the flash-flood dynamics and the type and spatial distribution of the associated impacts. The exceptionality of the rainstorm is further confirmed by the return period associated with the daily precipitation registered at the two long-term record stations, with $146.9 \mathrm{~mm}$ observed in the city of Funchal and $333.8 \mathrm{~mm}$ on the mountain top, corresponding to an estimated return period of approximately $290 \mathrm{yr}$ and $90 \mathrm{yr}$, respectively. Furthermore, the synoptic associated situation responsible for the flash-floods is analysed using different sources of information, e.g., weather charts, reanalysis data, Meteosat images and radiosounding data, with the focus on two main issues: (1) the dynamical conditions that promoted such anomalous humidity availability over the Madeira region on 20 February 2010 and (2) the uplift mechanism that induced deep convection activity.
\end{abstract}

\section{Introduction}

On the 20 February 2010 the island of Madeira was hit by torrential rainfall that triggered catastrophic flash-floods, accounting for a death toll of 45 , with roughly half of the victims (22) alone occurring in the capital city of Funchal, while 6 other persons were declared missing. It was the deadliest hydro-meteorological catastrophe in the Portuguese territory in the last four decades and the economic damage costs were estimated to be US\$1.9 billion (EM-DAT CRED, 2010). The island of Madeira is quite densely populated, particularly in its southern coast, with circa 267000 inhabitants in 2011 census, with 150000 (approximately $40 \%$ ) living in the Funchal district, one of the earliest tourism hot spots in Europe, currently with approximately 30000 hotel beds. In 2009, the archipelago received 1 million guests; this corresponds to an income of more than 255 Million Euro (INE-Instituto Nacional de Estatística, http://www.ine.pt).

Madeira is a mountainous island with $740.7 \mathrm{~km}^{2}$, located in the eastern subtropical area of the North Atlantic Ocean (Fig. 1a); Its orography (Fig. 1.b) is dominated by a vigorous volcanic landscape, with deep valleys, steeped slopes and scarps, exhibiting its highest elevations along a E-W oriented barrier, where the maximum altitude is achieved at the top of the eastern mountain range $(1861 \mathrm{~m}$ at Pico Ruivo). Located between the $30^{\circ}$ and $33^{\circ}$ latitude N, Madeira has a Mediterranean type climate moderated by the Atlantic Ocean, and since the island orographic barrier (E-W) has an almost perpendicular orientation with the prevailing wind direction (NE), temperature and rainfall vary remarkably between the northern and southern slopes. The northern slopes are more humid than the southern counterparts at the same altitude, while the amount of rainfall increases with altitude on both slopes (Prada et al., 2009). The mean annual precipitation varies between $600 \mathrm{~mm}$ in the Funchal district to close to $3000 \mathrm{~mm}$ at the top of the eastern mountain range (stations 43 and 25 in Fig. 1, respectively).

Relevant rain-induced natural hazards in Madeira are flash-floods, landslides, debris flows and less frequentlytsunamis, which can be caused by coastal rock slides (Rodrigues and Ayala-Carcedo, 2003). Unlike the Azores and Canary Islands, Madeira lacks major volcanic activity and is prone only to relatively modest earthquake events. Flashfloods constitute probably the most dangerous natural hazard 


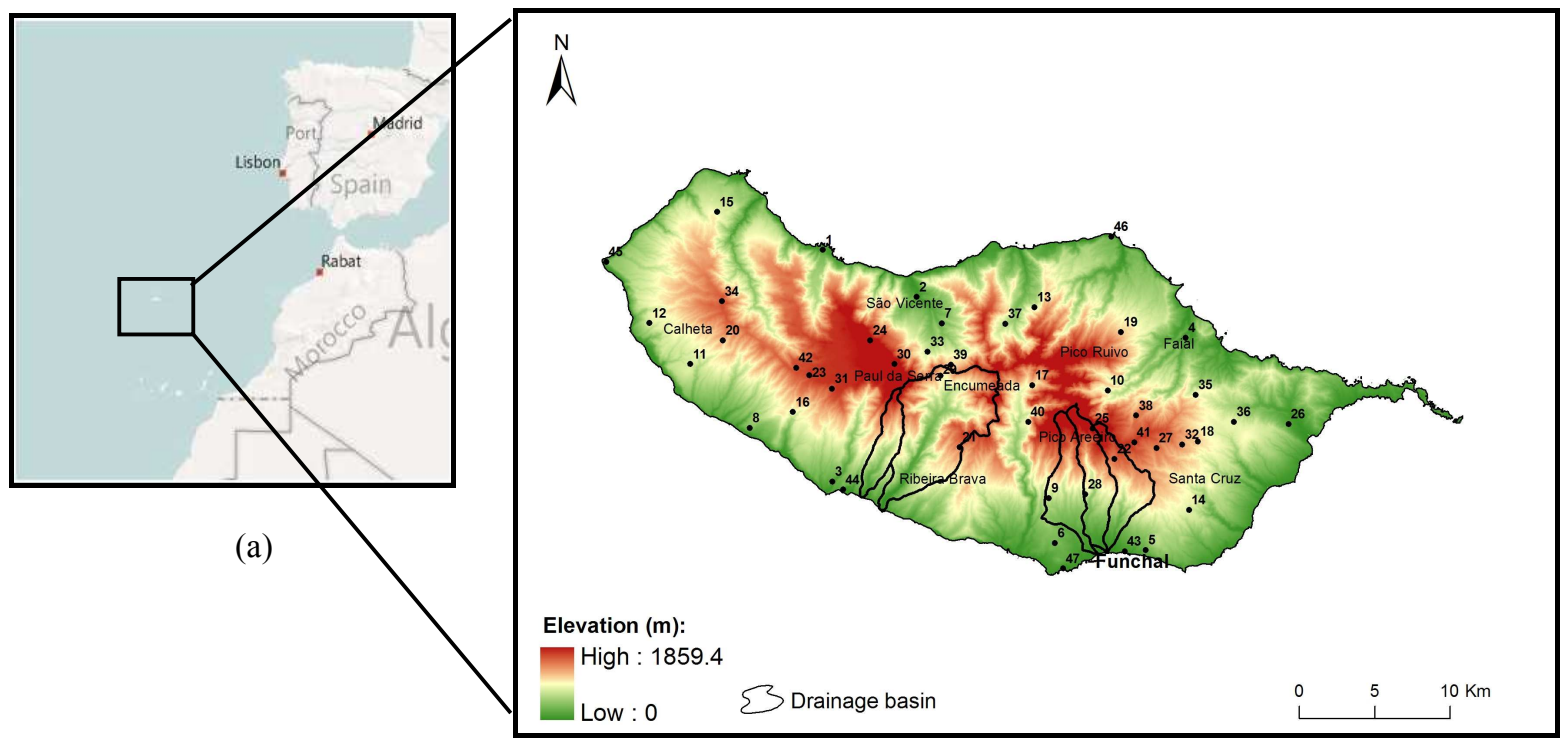

(b)

Fig. 1. Location (a) and relief (b) of the island of Madeira (Portugal). Dots are locations of the rain-gauge stations used in this study (names and description in Table 1). Limits of the drainage basins affected by the 20 February flash-floods and landslides are also shown (names and description in the text).

Table 1. Main flash-flood events in Madeira between 1800 and 2010 (SRES, 2010).

\begin{tabular}{lll}
\hline Date & Most affected areas & Casualties and damage \\
\hline 9 October 1803 & Funchal & $800-1000$ casualties \\
6 March 1929 & S. Vicente & 40 casualties, 11 houses destroyed \\
30 December 1939 & Madalena do Mar & 4 casualties \\
21 September 1972 & Santo António & 2 casualties \\
20 December 1977 & Estreito de Câmara de Lobos & 2 casualties and 45 dislodged \\
23 and 24 January 1979 & Machico, Porto da Cruz, Camacha, & 14 casualties \\
& Canhas, Calheta and Fajã do Penedo & \\
29 October 1993 & All the island & 4 casualties, 4 missed people, 306 dislodged, \\
& & 27 injured people, 76 houses destroyed \\
5 and 6 March 2001 & Curral das Freiras and S. Vicente & 4 casualties and 120 dislodged people \\
22 December 2009 & Madalena do Mar and S. Vicente & Houses and roads destroyed \\
February 2010 & Funchal and Ribeira Brava & 45 casualties, 6 missed people \\
\hline
\end{tabular}

in Madeira, where the phenomenon has the common name of "aluvião", referring to flash-floods affecting streams whose discharges and energy increase dramatically after intense rainfall episodes, dragging mud, blocks and debris, and producing a powerful and destructive current (Ribeiro, 1985). An inventory of flash-floods responsible for human casualties or severe damage compiled by Quintal (1999) refers 30 flashflood events after the historical catastrophe of 9 October 1803 - when more than 800 people were killed, mostly in Funchal - until the end of 1998. Taking into consideration the number of casualties or damage, a more recent compilation (SRES,
2010), indicates 9 main events of disastrous flash-floods over the 1800-2009 period (Table 1). Similar to the occurrence in October 1803, the damage suffered during the 20 February 2010 event was particularly harmful in the southern slope of the island, mainly in the Funchal city district. Examples of damages and destruction associated with the flash-floods in the downtown area of Funchal and Ribeira Brava, two of the most affected areas, are shown in Fig. 2. An extraordinary volume of solid material - debris and huge blocks - was dragged and deposited by the torrential flows. A systematic survey of the landslides produced in 20 February 2010 based 


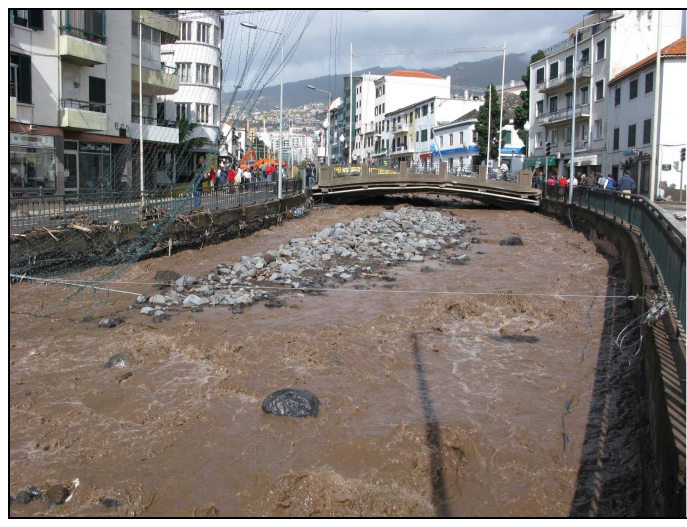

a)

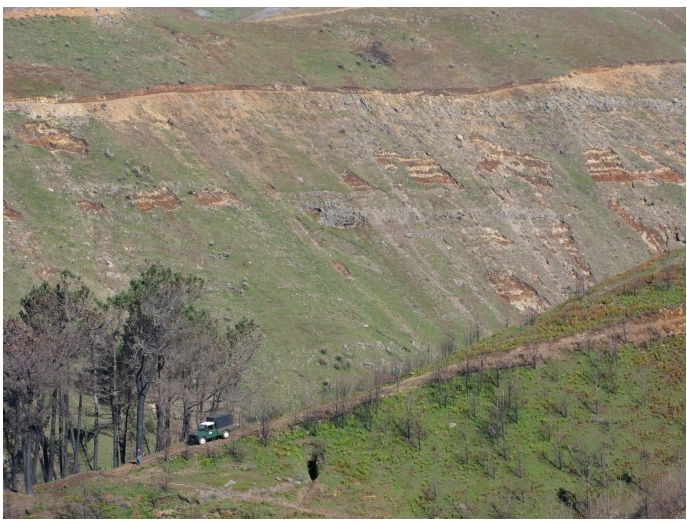

(b)

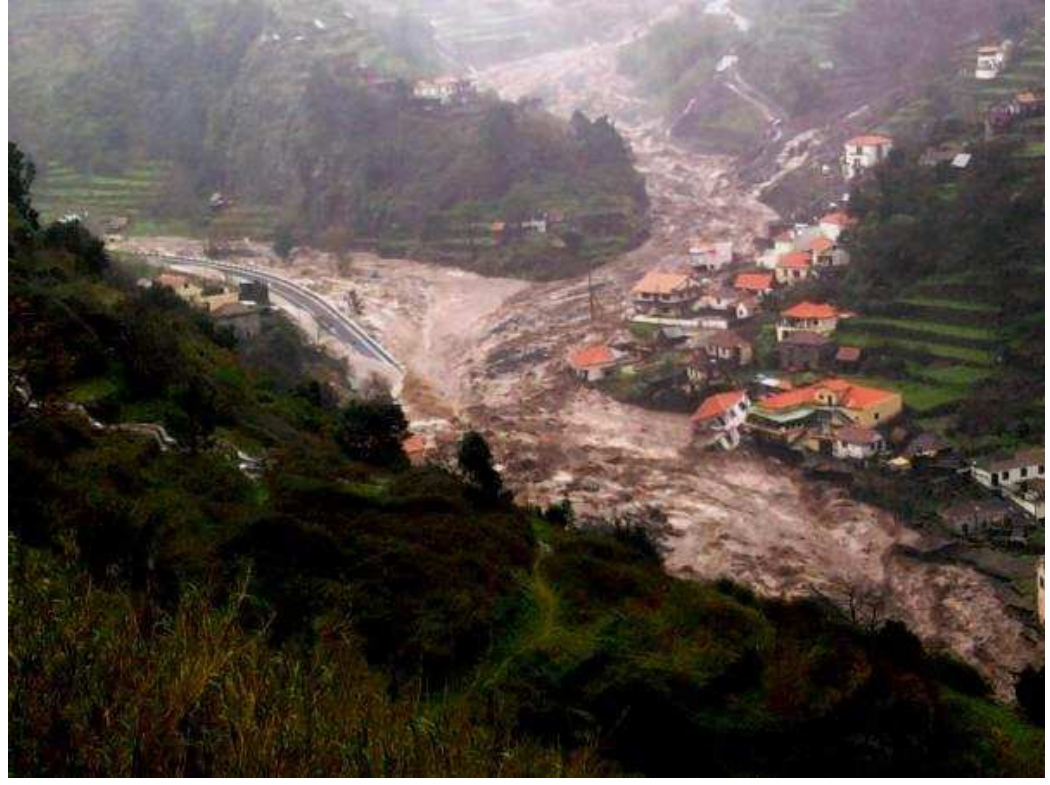

c)

Fig. 2. Photos showing the destructive effects of the 20 February 2010 flash-floods and landslides in: (a) downtown and (b) uplands; (c) Serra de Água, Ribeira Brava.

on remote-sensing analysis and validated by field data collection allowed the identification of 3291 landslides in Funchal drainage basins and 5172 landslides in the Ribeira Brava sector (SRES, 2010). According to the same report, as a result of this large number of landslides, it was estimated that a volume of at least $250000 \mathrm{~m}^{3}$ of solid material was deposited in the Funchal urban areas.

The hydrological and geomorphological impacts related to this extreme event were concentrated over five drainage basins (limits shown in Fig. 1) belonging to the southern flank of the island, three of them located in the Funchal region (Ribeira de São João, Ribeira de Santa Luzia and Ribeira de João Gomes) while the remaining belong to the Ribeira Brava sector (Ribeira da Tabua, Ribeira Brava). These drainage basins are very small (with areas varying between $8.8 \mathrm{~km}^{2}$ and $15 \mathrm{~km}^{2}$ ), and their shape is elongated, except in the case of Ribeira Brava basin, the larger one, with $40.9 \mathrm{~km}^{2}$ and exhibiting a funnel shape. The five drainage basins are also characterised by the dominance of steep slopes (mean slopes varying between 28 and $37 \%$, with some areas with slopes over $50 \%$ ) and short times of concentration (inferior to $3.3 \mathrm{~h}$ in all cases, estimations made using the Temez method, SRES 2010). These two parameters are relevant features for flash-flooding production. According to SRES (2010), the estimated peak flow for the 20 February 2010 event reached $234 \mathrm{~m}^{3} \mathrm{~s}^{-1}$ in the Ribeira de João Gomes, close to $300 \mathrm{~m}^{3} \mathrm{~s}^{-1}$ in São João and Santa Luzia streams and $663 \mathrm{~m}^{3} \mathrm{~s}^{-1}$ in Ribeira Brava.

The complexity of the phenomenon studied here and the extreme severity of its impacts, resulted from the combination of debris-flows, landslides and flash-flooding, triggered and produced in a short time lapse as a consequence 
of an intense precipitation episode (the "paroxysm", in 20 February 2010), but also controlled by antecedent and longer duration rainfalls, providing crucial pre-existing conditions to the disaster (the anomalous wet 2010 winter in Madeira). In fact, the intense rainfall event responsible for the 20 February 2010 flash-floods in Madeira occurred during a particularly anomalous wet winter affecting most sectors of southern Iberian Peninsula (Andrade et al., 2011; Ball, 2011; Vicente-Serrano et al., 2011), and also the Madeira archipelago. As described in detail below, several stations registered more than the triple of the average precipitation during the winter (DJF) months. Moreover, the extreme rainfall event of the 20 February was preceded by very high precipitation during the previous months and, among others, an intense precipitation episode occurred three weeks earlier (2 February), affecting mostly the central mountain range with severe flooding impacts being felt in a stream of the northern coast (Faial). Undoubtedly, the accumulated precipitation registered throughout the winter contributed to saturate soils, inducing favourable conditions to increase and accelerate surface runoff, aggravating flash-flood susceptibility in the Madeira drainage basins (SRES, 2010). Therefore, the exceptionality of the 20 February rainstorm episode should be analysed within the context of the whole winter, as the impacts observed during the event were clearly amplified by the continuous mounting of these predisposing factors for flash-flood occurrence.

This investigation is focused on the meteorological features of this extreme event, with the following main objectives:

1. To provide a detailed spatial and temporal characterisation of the precipitation observed on the 20 February 2010 that triggered the flash-floods and landslides. Daily and hourly precipitation records from the available rain-gauge stations network are evaluated in order to reconstitute the temporal evolution of the rainstorm, as well as its geographic incidence, contributing to understand the flash-flood dynamics and the type and spatial distribution of the associated impacts.

2. To estimate the exceptionality of the rainstorm, using the longest monthly, daily and sub-daily precipitation series available for Madeira, with a special emphasis on the computation of estimates of the return periods of daily precipitation observed during the 20 February 2010 event.

3. To describe the most relevant atmospheric factors involved in this extreme rainfall event, identifying the main atmospheric synoptic conditions and also relevant physical mechanisms that favoured its development.

\section{Data and methods}

The present research results from the collection, compilation and analysis of diverse types of data, information that can be considered to be included in two main topics: precipitation data and atmospheric data.

\subsection{Precipitation data}

The Island of Madeira is well covered by weather stations with rain-gauges. Unfortunately these stations are maintained by three different organizations, namely: (1) IM/Instituto de Meteorologia, (2) IGA/Investimentos e Gestão da Água and (3) LREC/Laboratório Regional de Engenharia Civil. Since our aim is to obtain details on the extension and intensity of the event, a careful preliminary work of data assembling was performed to retrieve a homogenous precipitation dataset, allowing a wide geographical coverage of the island and to be sufficiently representative of its complex orography. Thus, daily and hourly precipitation data from a total of 47 meteorological and raingauge stations were gathered. Their location is depicted in Fig. $1 \mathrm{~b}$ and their main characteristics are presented in Table 2. We are confident that the raingauge network density (exceeding 6 stations $/ 100 \mathrm{~km}^{2}$ ) is sufficiently representative, in spite of the steep orography that dominates the island landscape. The precipitation data from these 47 stations was used to produce hourly and daily precipitation maps relative to the 20 February 2010 following the application of appropriate geostatistical techniques. In this regard, the ordinary kriging was chosen as interpolation method, estimating specific variogram models for each map (e.g., Goovaerts, 1997; Showalter, 2010).

In addition to these precipitation data, long-term series of annual maximum daily precipitation were collected, allowing the evaluation of the return period, i.e., an objective measure of the long-term exceptionality of the 20 February event. Unfortunately, only two series with appropriate temporal length (with ongoing observations and at least more than $60 \mathrm{yr}$ of records) - Funchal/Observatório (no. 43, Fig. 1b) and Areeiro (no. 25, Fig. 1b) - were available and used for this analysis. Moreover, both series are not complete and their quality was also affected by changes in the instruments along the total period of collected information, starting in 1936 and ending in 2010. Nevertheless, the number of gaps was $5 \%$ (8\%) of missing data for Funchal (Areeiro), which was considered to be acceptable when computing the return period estimations.

\subsection{Synoptic and atmospheric data}

The synoptic context of the 20 February 2010 extreme event was analysed using different sources of information. Weather charts covering the Eastern Atlantic were obtained from the German Weather Service (Deutscher Wetterdienst; DWD) 
Table 2. Description of meteorological stations and raingauges used in this study.

\begin{tabular}{|c|c|c|c|c|}
\hline $\begin{array}{r}\text { Code } \\
\text { (see Fig. 1) }\end{array}$ & Designation & $\begin{array}{l}\text { Longitude } \\
\text { (W) }\end{array}$ & $\begin{array}{l}\text { Latitude } \\
\text { (N) }\end{array}$ & $\begin{array}{r}\text { Altitude } \\
\text { (m) }\end{array}$ \\
\hline 1 & Seixal (LREC) & $17^{\circ} 06^{\prime} 21^{\prime \prime}$ & $32^{\circ} 49^{\prime} 12^{\prime \prime}$ & 70 \\
\hline 2 & S. Vicente, Posto Florestal (LREC) & $17^{\circ} 02^{\prime} 19^{\prime \prime}$ & $32^{\circ} 47^{\prime} 35^{\prime \prime}$ & 120 \\
\hline 3 & Ponta do Sol (LREC) & $17^{\circ} 05^{\prime} 44^{\prime \prime}$ & $32^{\circ} 40^{\prime} 56^{\prime \prime}$ & 130 \\
\hline 4 & Lombo dos Palheiros (LREC) & $16^{\circ} 50^{\prime} 52^{\prime \prime}$ & $32^{\circ} 46^{\prime} 18^{\prime \prime}$ & 212 \\
\hline 5 & São Gonçalo (LREC) & $16^{\circ} 52^{\prime} 24^{\prime \prime}$ & $32^{\circ} 38^{\prime} 41^{\prime \prime}$ & 220 \\
\hline 6 & LREC - EMA (LREC) & $16^{\circ} 56^{\prime} 15^{\prime \prime}$ & $32^{\circ} 38^{\prime} 53^{\prime \prime}$ & 260 \\
\hline 7 & Achada do Til (LREC) & $17^{\circ} 01^{\prime} 13^{\prime \prime}$ & $32^{\circ} 46^{\prime} 39^{\prime \prime}$ & 300 \\
\hline 8 & Massapez (LREC) & $17^{\circ} 09^{\prime} 17^{\prime \prime}$ & $32^{\circ} 42^{\prime} 47^{\prime \prime}$ & 300 \\
\hline 9 & Trapiche (LREC) & $16^{\circ} 56^{\prime} 34^{\prime \prime}$ & $32^{\circ} 40^{\prime} 29^{\prime \prime}$ & 590 \\
\hline 10 & Fajã Nogueira (LREC) & $16^{\circ} 54^{\prime} 08^{\prime \prime}$ & $32^{\circ} 44^{\prime} 22^{\prime \prime}$ & 629 \\
\hline 11 & Prazeres (LREC) & $17^{\circ} 11^{\prime} 52^{\prime \prime}$ & $32^{\circ} 45^{\prime} 01^{\prime \prime}$ & 632 \\
\hline 12 & Fajã Ovelha (LREC) & $17^{\circ} 13^{\prime} 38^{\prime \prime}$ & $32^{\circ} 46^{\prime} 27^{\prime \prime}$ & 635 \\
\hline 13 & Fajã do Penedo (LREC) & $16^{\circ} 57^{\prime} 19^{\prime \prime}$ & $32^{\circ} 47^{\prime} 18^{\prime \prime}$ & 637 \\
\hline 14 & Camacha (LREC) & $16^{\circ} 50^{\prime} 36^{\prime \prime}$ & $32^{\circ} 40^{\prime} 09^{\prime \prime}$ & 675 \\
\hline 15 & Porto Moniz, Est. Zoot. - EMA (LREC) & $17^{\circ} 10^{\prime} 52^{\prime \prime}$ & $32^{\circ} 50^{\prime} 29^{\prime \prime}$ & 675 \\
\hline 16 & Pinheiro Fora (LREC) & $17^{\circ} 07^{\prime} 28^{\prime \prime}$ & $32^{\circ} 43^{\prime} 23^{\prime \prime}$ & 750 \\
\hline 17 & Curral das Freiras (LREC) & $16^{\circ} 57^{\prime} 20^{\prime \prime}$ & $32^{\circ} 44^{\prime} 31^{\prime \prime}$ & 800 \\
\hline 18 & Casa Velha (P.F.) (LREC) & $16^{\circ} 50^{\prime} 17^{\prime \prime}$ & $32^{\circ} 42^{\prime} 36^{\prime \prime}$ & 880 \\
\hline 19 & Pico das Pedras (P.F.) (LREC) & $16^{\circ} 53^{\prime} 37^{\prime \prime}$ & $32^{\circ} 46^{\prime} 28^{\prime \prime}$ & 920 \\
\hline 20 & Pico Verde - EMA (LREC) & $17^{\circ} 10^{\prime} 30^{\prime \prime}$ & $32^{\circ} 45^{\prime} 54^{\prime \prime}$ & 1020 \\
\hline 21 & Trompica, Posto Florestal (LREC) & $17^{\circ} 00^{\prime} 22^{\prime \prime}$ & $32^{\circ} 42^{\prime} 15^{\prime \prime}$ & 1188 \\
\hline 22 & PEF EMA (LREC) & $16^{\circ} 53^{\prime} 48^{\prime \prime}$ & $32^{\circ} 41^{\prime} 56^{\prime \prime}$ & 1300 \\
\hline 23 & Pico da Urze (LREC) & $17^{\circ} 06^{\prime} 48^{\prime \prime}$ & $32^{\circ} 44^{\prime} 46^{\prime \prime}$ & 1365 \\
\hline 24 & Estanquinhos (LREC) & $17^{\circ} 04^{\prime} 15^{\prime \prime}$ & $32^{\circ} 46^{\prime} 00^{\prime \prime}$ & 1590 \\
\hline 25 & Areeiro-LREC & $16^{\circ} 54^{\prime} 45^{\prime \prime}$ & $32^{\circ} 43^{\prime} 00^{\prime \prime}$ & 1590 \\
\hline 26 & Machico - EMA (LREC) & $16^{\circ} 46^{\prime} 26^{\prime \prime}$ & $32^{\circ} 43^{\prime} 17^{\prime \prime}$ & 170 \\
\hline 27 & Meia Serra (IGA) & $16^{\circ} 52^{\prime} 02^{\prime \prime}$ & $32^{\circ} 42^{\prime} 20^{\prime \prime}$ & 1100 \\
\hline 28 & ETA Alegria (IGA) & $16^{\circ} 55^{\prime} 00^{\prime \prime}$ & $32^{\circ} 40^{\prime} 39^{\prime \prime}$ & 611 \\
\hline 29 & Encumeada (IGA) & $17^{\circ} 01^{\prime} 15^{\prime \prime}$ & $32^{\circ} 44^{\prime} 47^{\prime \prime}$ & 854 \\
\hline 30 & Bica da Cana (IGA) & $17^{\circ} 03^{\prime} 12^{\prime \prime}$ & $32^{\circ} 45^{\prime} 10^{\prime \prime}$ & 1585 \\
\hline 31 & Cova Grande (IGA) & $17^{\circ} 05^{\prime} 50^{\prime \prime}$ & $32^{\circ} 44^{\prime} 14^{\prime \prime}$ & 1340 \\
\hline 32 & Ovil (IGA) & $16^{\circ} 50^{\prime} 56^{\prime \prime}$ & $32^{\circ} 42^{\prime} 29^{\prime \prime}$ & 1014 \\
\hline 33 & Rosário, Fajã Rodrigues (IGA) & $17^{\circ} 01^{\prime} 48^{\prime \prime}$ & $32^{\circ} 45^{\prime} 38^{\prime \prime}$ & 575 \\
\hline 34 & Fonte do Bispo (IGA) & $17^{\circ} 10^{\prime} 35^{\prime \prime}$ & $32^{\circ} 47^{\prime} 17^{\prime \prime}$ & 1245 \\
\hline 35 & Santo Serra, Lamaceiros (IGA) & $16^{\circ} 50^{\prime} 24^{\prime \prime}$ & $32^{\circ} 44^{\prime} 16^{\prime \prime}$ & 784 \\
\hline 36 & Santo da Serra, Quinta (IGA) & $16^{\circ} 48^{\prime} 46^{\prime \prime}$ & $32^{\circ} 43^{\prime} 20^{\prime \prime}$ & 660 \\
\hline 37 & Achada da Madeira (IGA) & $16^{\circ} 58^{\prime} 32^{\prime \prime}$ & $32^{\circ} 46^{\prime} 41^{\prime \prime}$ & 521 \\
\hline 38 & Chão das Feiteiras (IGA) & $16^{\circ} 52^{\prime} 54^{\prime \prime}$ & $32^{\circ} 43^{\prime} 29^{\prime \prime}$ & 1180 \\
\hline 39 & Chão dos Louros (IGA) & $17^{\circ} 00^{\prime} 49^{\prime \prime}$ & $32^{\circ} 45^{\prime} 11^{\prime \prime}$ & 900 \\
\hline 40 & Curral das Freiras ETA (IGA) & $16^{\circ} 57^{\prime} 29^{\prime \prime}$ & $32^{\circ} 43^{\prime} 12^{\prime \prime}$ & 743 \\
\hline 41 & Poiso, Posto Florestal (IGA) & $16^{\circ} 52^{\prime} 58^{\prime \prime}$ & $32^{\circ} 42^{\prime} 32^{\prime \prime}$ & 1360 \\
\hline 42 & Ribeira do Alecrim (IGA) & $17^{\circ} 07^{\prime} 22^{\prime \prime}$ & $32^{\circ} 44^{\prime} 58^{\prime \prime}$ & 1293 \\
\hline 43 & Funchal/Obs. (IM) & $16^{\circ} 53^{\prime} 18^{\prime \prime}$ & $32^{\circ} 38^{\prime} 38^{\prime \prime}$ & 58 \\
\hline 44 & Lugar de Baixo (IM) & $17^{\circ} 05^{\prime} 17^{\prime \prime}$ & $32^{\circ} 40^{\prime} 39^{\prime \prime}$ & 15 \\
\hline 45 & Ponta do Pargo (IM) & $17^{\circ} 15^{\prime} 31^{\prime \prime}$ & $32^{\circ} 48^{\prime} 37^{\prime \prime}$ & 312 \\
\hline 46 & São Jorge (IM) & $16^{\circ} 54^{\prime} 06^{\prime \prime}$ & $32^{\circ} 49^{\prime} 52^{\prime \prime}$ & 185 \\
\hline 47 & Funchal/Lido (IM) & $16^{\circ} 55^{\prime} 53^{\prime \prime}$ & $32^{\circ} 37^{\prime} 58^{\prime \prime}$ & 25 \\
\hline
\end{tabular}

and were useful for the recognition of the main features of the associated synoptic atmospheric circulation. Atmospheric fields were extracted from the ERA-Interim reanalysis (ECWMF) dataset, available on a $1.5^{\circ} \times 1.5^{\circ}$ latitude/longitude mesh and are used to analyse the dynamical aspects of the meteorological event. The thermodynamic environment associated with this event is characterised by two instability parameters, the Lifted index (LI) and CAPE (Convective Available Potential Energy). The LI is the temperature difference between an air parcel lifted adiabatically and the environment temperature at $500 \mathrm{hPa}$ (e.g., Galway, 1958). Negative values of LI indicate that the atmosphere is unstable. The more negative values of LI, the higher the probability of thunderstorm occurrence. CAPE is the 


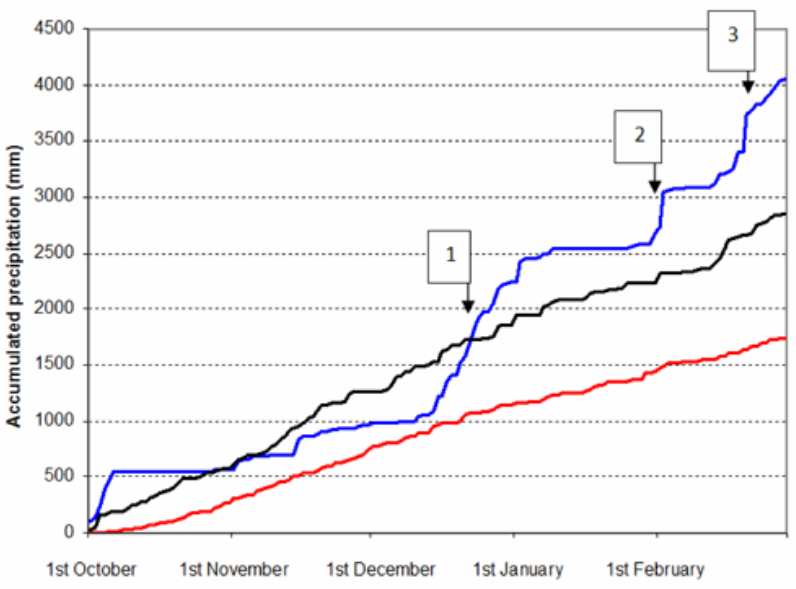

a)

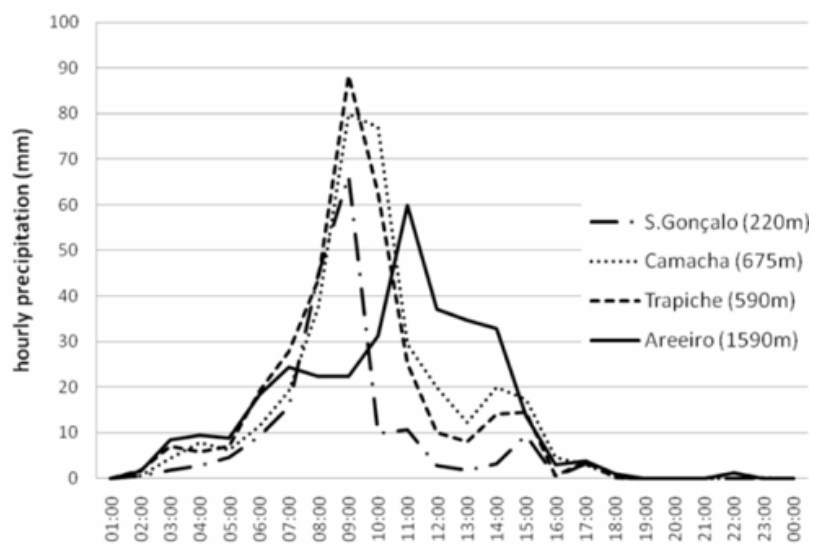

b)

Fig. 3. (a)Accumulated daily precipitation (ADP) in Areeiro (station number 25 in Fig. 1) between 1 October 2009 and 28 February 2010 (blue line) and comparison with the long-term median (red line) and 95th percentile (dark line) of the ADP for the same time span, estimated over the 1936/37-2008/09 period. Indicated is the occurrence of three events (1) 22 December 2009 flash flood (2) 2 February 2010 heavy rainfall event (3) 20 February 2010 flash flood. Note: the represented precipitation data were recorded in different meteorological stations, however, just separated by a few metres and located approximately at the same height ( $20 \mathrm{~m}$ of difference). (b) Hourly evolution of the 20 February 2010 rainstorm in Madeira, in four selected udographic stations from the Funchal city surroundings. Indicated hours in the abcissae axis are the ending time of the corresponding precipitation amount. The altitude (metres) of the four rain-gauge stations is inserted in the legend.

amount of energy a parcel of air would have if lifted vertically through the atmosphere (Moncrieff and Green, 1972; Doswell and Rasmunsen, 1994). Positive CAPE indicate positive buoyancy of an air parcel being, thus, an indicator of atmospheric instability. The humidity transport associated with this event has been calculated based on this data using 3-D backward trajectories (Methven, 1997). This tool allows the tracing of humidity (or other atmospheric contents) of an air parcel and has been used, therefore, in some studies (e.g., Methven et al., 2001). In addition, the diagnostic of the intense mid-latitude cyclone system associated to the 20 February 2010 flash-floods in Madeira was also performed using appropriate sequences of Meteosat-9 satellite images (infra-red and water vapour channels, and also from the derived product Multi-Sensor Precipitation Estimate, available at www.eumetsat.int). Further, the evolution of local conditions of the tropospheric column was reconstituted using data from the radiosounding station in Funchal. Unfortunately, only one sounding per day is launched (at 12:00 UTC). Sounding plots, thermodynamic parameters and stability indices were computed using the RAwinsonde Observation (RAOB) software (Schewchuk, 2002).

\section{Rainfall analysis}

This section is devoted to the temporal and spatial characterisation of the precipitation associated with this prominent event. We start by analysing the precipitation during the antecedent months leading to the extreme event. It must be underlined that the accumulated precipitation in the previous months was very important for the phenomenon studied here. The large number of landslides and debris flows suddenly produced in the 20 February 2010 , are connected with the accumulated rainfall. This factor aggravated the severity of the impacts of the flash floods, providing an enormous amount of rocks, debris and solid material to be dragged into the valleys. Afterwards, a detailed description of the spatial and temporal evolution of the precipitation event is provided. Finally, the exceptionality of the event is evaluated with long records that allow computing the return periods associated with the event.

\subsection{The extremely wet 2009-2010 winter in the Madeira Islands}

The analysis of Fig. 3a allows the comparison of the accumulated daily precipitation (ADP) between the beginning of the 2010 hydrological year (starting 1 October 2009) and the end of February 2010 (blue line) with the long-term median (red line) and 95th percentile of the ADP (black line) for the same 72-yr long period (i.e., 1937/38-2008/09). The precipitation data shown in this figure (Areeiro station, no. 25 in Fig. 1b) is representative of the precipitation records in the upper part of the eastern mountains of the island, close to one of its highest peaks. The winter was extremely wet at Areeiro (above $4000 \mathrm{~mm}$ of rainfall between 1 October 2009 and 28 February 2010), exceeding more than twice the median 
amount of ADP obtained between 1937 and 2008 for the same period. Furthermore, the accumulated ADP at the end of February was also significantly higher than the corresponding 95th percentile; in fact, the winter of 2009/2010 was the rainiest wet season since 1937. Nevertheless, the relative rank of this winter was not constant throughout the temporal window analysed in Fig. 3a, starting with a wet October, the ADP remained slightly above the median until mid December, increasing to higher percentile only afterwards. In fact, after the 22 December 2009, the ADP begun to exceed the 95th percentile and kept above this threshold until the end of February. Therefore, this comparative analysis clearly demonstrates that the 2009/2010 rainy season was exceptionally wet at the mountainous region a few kilometres above the Funchal bay area. In particular, heavy precipitation episodes with extremely high amounts at daily scale occurred: 22 December 2009, 2 February 2010 and 20 February 2010 (here described). These events are marked 1-3 in Fig. 3a.

In the Funchal area, the anomalously wet 2010 winter (DJF) was even more extreme (in relative terms) than what has been described for the Madeira uplands. The accumulated precipitation in 2010 winter was $997 \mathrm{~mm}$ in Funchal/Observatory station (no. 43 in Fig. 1b), largely exceeding the 95th percentile of its historical records for this season, which is close to $700 \mathrm{~mm}$. In particular, the precipitation amount observed at this station during February $-458.7 \mathrm{~mm}$ - corresponds to the new absolute all-time record since 1865 , i.e., since the beginning of regular observations in the island. We would like to stress that this value exceeds 8 times the median value of February precipitation (obtained for the normal 1971-2000 period). This analysis confirms that the 20 February 2010 event was preceded by an equally outstanding anomalous accumulated precipitation, particularly on the upper parts of Eastern Mountains, which probably lead to increase the slope instability at the upstream sectors of the Funchal catchments and, thus, inducing favourable conditions for triggering landslides. The control of rainfall on landslides differs substantially depending upon landslide depth and kinematics and the affected material. Shallow soil slips and rapid debris flows are typically activated by a short period of very intense rain, while deep-seated rotational and translational slides are usually associated with less intense rainfall occurring in a period lasting several weeks to several months (e.g., Zêzere et al., 2005).

\subsection{Spatial features and temporal evolution of the 20 February 2010 rainstorm}

A synthetic overview of the 20 February rainfall for selected stations is depicted in Fig. 3b, where we can appreciate the evolution of hourly precipitation throughout the day relative to four selected rain-gauge stations placed in the surrounding areas of the Funchal urban district. Among these rain-gauge stations, São Gonçalo ( $220 \mathrm{~m}$ of altitude, no. 5 in Fig. 1b) is the lowest altitude station and is located east of Funchal. Trapiche (590 m, no. 9 in Fig. 1b) and Camacha (690 m, no. 14 in Fig. 1b) are representative sites from the intermediate sectors of the slopes and are respectively located to the west and east of the Funchal city area. Areeiro $(1590 \mathrm{~m}$, no. 25 in Fig. 1b) is the most elevated rain-gauge represented in Fig. 3b, illustrating the rainstorm on the upstream sector of the drainage basin that cross the Funchal urban district, and where flash-floods occurred.

The total duration of the rainstorm was quite unusual with roughly 14 consecutive hours of uninterrupted precipitation over most of the Island, starting at 03:00 UTC and ending only at 17:00 UTC. The hourly precipitation intensity increased gradually during the early morning hours of 20 February in this southern sector of the Madeira Island. Interestingly, the most intense and critical period of the storm hit initially the lower and midway sectors of the slopes (Fig. 3b), where the hourly rainfall intensity reached at least $60 \mathrm{~mm} \mathrm{~h}^{-1}$ between 08:00 and 09:00 UTC. At this stage, the precipitation was much lower in the upper sectors of the mountainous area, such as the Areeiro Peak. However, during the following hours, while the precipitation started to decrease at lower altitudes, an increase can be observed at higher levels (e.g., Areeiro), with a maximum at 11:00 UTC, when landslides and floods were already occurring and aggravating their impacts even more. Afterwards, and until 14:00 UTC, very abundant precipitation was accumulated at the upstream sectors of the drainage systems, especially those that flow into the Funchal coastal areas, as it is demonstrated by the hourly intensity rates above $30 \mathrm{~mm} \mathrm{~h}^{-1}$ in the Areeiro rain-gauge station (Fig. 3b).

In order to obtain an appropriate reconstitution of the space-time variability of the precipitation associated with the 20 February rainstorm in Madeira, hourly maps were elaborated using all available information from the 47 rain-gauges of the island (Fig. 4). These eleven hourly maps illustrate the evolution of the rainstorm between 05:00 and 16:00 UTC, thus, allowing a detailed representation of the event (the first three hours are omitted as precipitation amounts were relatively small). Figure 4 documents the initial phase of the event, when precipitation began to batter the southern flanks of the island, especially its eastern sectors, including the Funchal district. From 08:00 to 09:00 UTC, the rainfall was more intense at lower sectors of the southern slopes, with intensities close to $35 \mathrm{~mm} \mathrm{~h}^{-1}$. In the following two hours, the precipitation rate increased (up to 60 to $80 \mathrm{~mm} \mathrm{~h}^{-1}$ ) and was more concentrated over the intermediate elevation sectors around the Funchal region, at slope levels between 500 and $1000 \mathrm{~m}$ of altitude. The most intense cores of severe precipitation after 10:00 UTC mainly affected areas close to Funchal or its surroundings. From 11:00 UTC onwards, the most intense precipitation moved northwards and was mostly confined to the uplands and higher peaks of the central ridge of the island. Throughout this period, the spatial pattern of precipitation distribution is generally marked by the major 

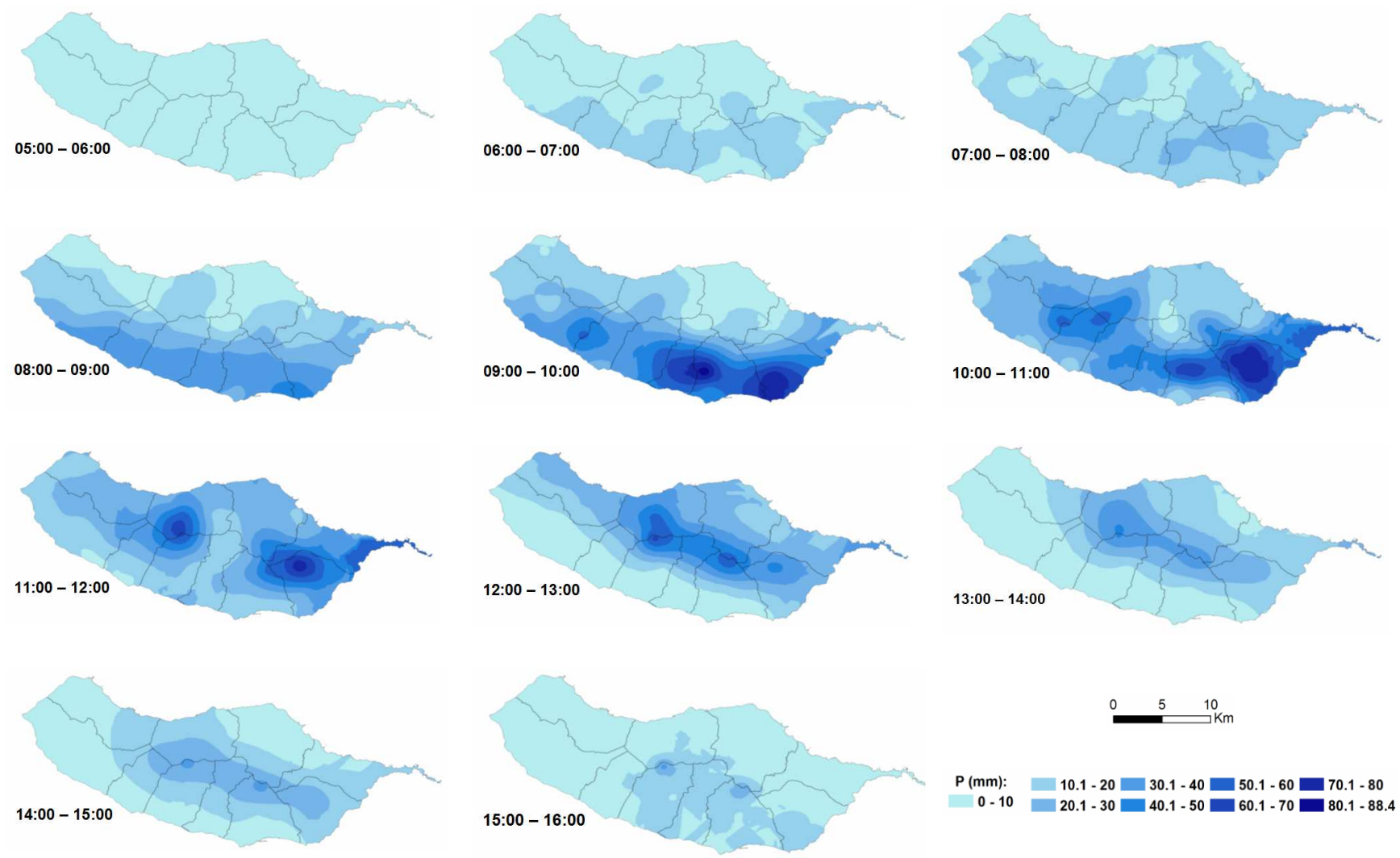

Fig. 4. Hourly precipitation in Madeira, 20 February 2010, between 05:00 UTC and 16:00 UTC. The maps are based on data from the same rain-gauge network represented in Fig. 1 (locations) and listed in Table 2.

topographic contrasts (depicted in Fig. 1b), suggesting that the orography played an important role to enhance and focus the event, resulting in a longer and even rainier storm.

The total daily precipitation amounts for the 20 February 2010 in Madeira are shown in Fig. 5a. Since no relevant showers occurred after its end 17:00 UTC, the precipitation distribution is representative for the whole event. Two major findings emerge from the analysis of Fig. 5a: (a) the large area of the island $(>50 \%)$ with total precipitation inside the $250 \mathrm{~mm}$ isoyeth limits; and (b) the existence of two main cores of extremely abundant precipitation, with amounts varying between 250 and $370 \mathrm{~mm}$, one located over the uplands and southern slopes of the eastern mountains (Areeiro plateau), and another one centred over the central plateau sector (Paúl da Serra and Encumeada). A closer look at Fig. 5a indicates that the Funchal area was entirely surrounded by the crescent pattern that characterises the southeastern peak of intense rainfalls, which explains the severity of flash-floods, landslides and debris-flows impacts on its drainage basins (see example in Fig. 2b). On the other hand, the second precipitation peak over the central plateau is responsible for the catastrophic impacts of floods and landslides in the Ribeira Brava area, located further west in the southern flank of the Island (Fig. 1b). The main cores of excessive rainfall may be expressed by mapping the total number of hours with precipitation above $10 \mathrm{~mm}$ (Fig. $5 \mathrm{~b}$; SRES, 2010). The period of sustained intense precipitation was considerably long, varying from five to ten consecutive hours over extended areas, which was, very probably, a critical condition to trigger the large number of landslides and other complex slope movements observed in the two main affected sectors (i.e., Funchal and Ribeira Brava, cf. Fig. 5b). Undoubtedly, the effects of such a large number of landslides, providing an outstanding volume of solid material to be dragged along streams, accounted for aggravating flashflooding impacts, resulting in the catastrophic and deadly event on the lower sectors of the small drainage basins.

\subsection{Assessment of the precipitation exceptionality}

The estimation of return periods is a classical approach in order to evaluate the exceptionality and magnitude of extreme meteorological events. This technique uses the extreme values analysis, the branch of probability and statistics that is used to make inferences about the size and frequency of extreme events (Storch and Zwiers, 2003). The proprieties of some of the most used extreme values distributions in climatology and hydrological sciences were described by 


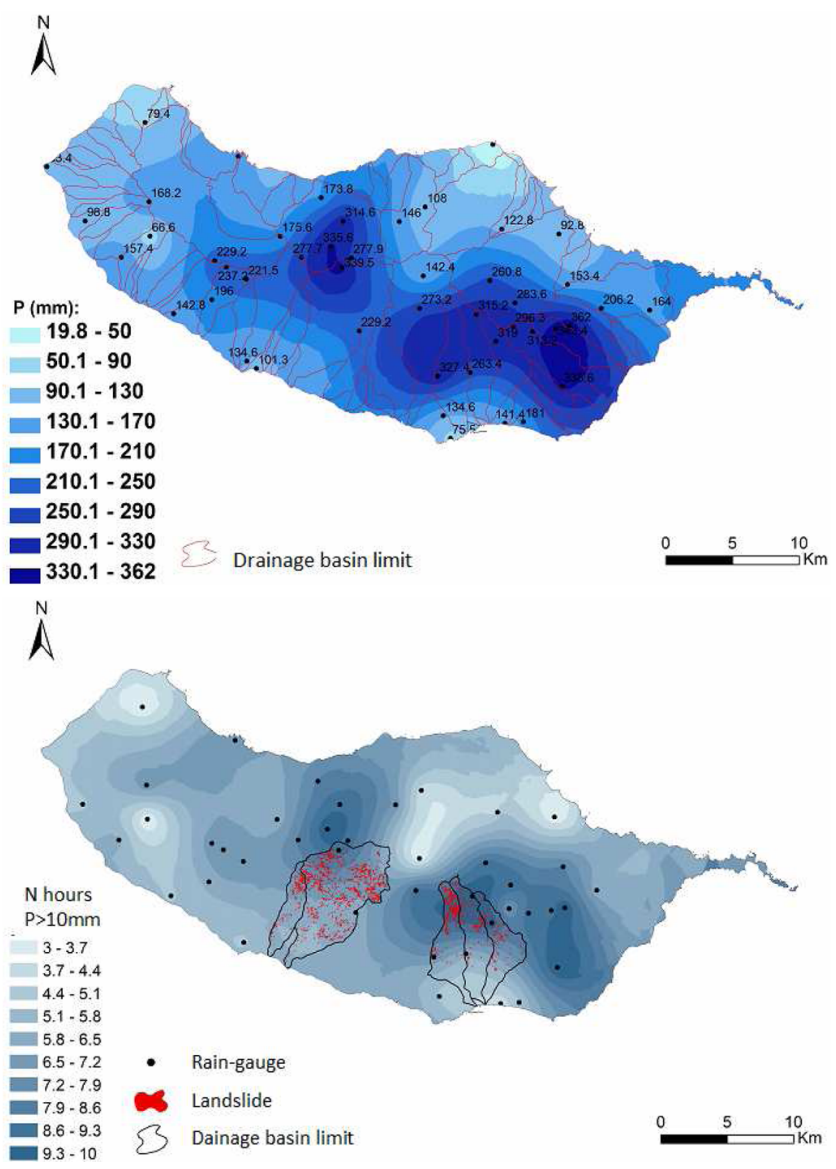

Fig. 5. (a) Total daily precipitation in Madeira (00:00-24:00 UTC), 20 February 2010. The map is based on data from the same raingauge network represented in Fig. 1 (station names are listed in Table 1). (b) Number of hours with precipitation above $10 \mathrm{~mm}$ and landslides distribution on Funchal and Ribeira Brava areas. This map is based on a subset of the network presented in Fig. 1, consisting only in udographic stations. Source: SRES, 2010.

Gumbel (1958) and recent reviews document a large number of applications (e.g., Coles, 2001; Alexandersson et al., 2001; Svenson and Jones, 2010). The availability of longterm series of the parameter to be analysed is a mandatory condition to carry out this type of investigation in an appropriate way, which represents in many cases a significant constraint. In the present study, the scarce availability of longterm series posed a problem. Another problem is that the archives only contain the precipitation accumulation for fixed periods (e.g., $24 \mathrm{~h}$ beginning at 09:00 UTC), instead of accumulations over a moving window (e.g., 24-h period).

With regard to the precipitation series of annual maxima within $24 \mathrm{~h}$, appropriate long-term records (1936-2010) are only available for two meteorological stations: Areeiro and Funchal/Observatory. A number of experiments were conducted in order to fit the most commonly used extreme value distributions to the data. The best fitting model was obtained with the GEV distribution, ranking the set of results from three standard tests to evaluate the goodness of fit: Kolgomorov-Smirnov, Anderson-Darling and Chi-squared tests (e.g., Wilks, 2005). Return periods for the $24 \mathrm{~h}$ rainfall observed for the 20 February 2010 for both sites confirm the exceptionality of the rainstorm. In the case of the mountainous Areeiro station, the $24 \mathrm{~h}$ amount detected $(333.8 \mathrm{~mm})$ corresponds to an estimated return period of approximately $90 \mathrm{yr}$. In contrast, the $24 \mathrm{~h}$ amount observed in Funchal/Observatory $(146.9 \mathrm{~mm})$ corresponds to a return period estimated to be in the order of $290 \mathrm{yr}$, thus, an even less frequent event.

Caution is required when estimating such long return periods, as they are much longer than the time series used to compute them. In any case this statistical approach clearly suggests that the 20 February 2010 extreme event can be classified as exceptional for both stations, although even more outstanding in the Funchal area than at the top of the Eastern mountains. Moreover, it must be stressed that almost $80 \%$ of this extreme daily precipitation observed in the Funchal/Observatory occurred within a six hours period (08:00 and 14:00 UTC). This period of sustained intense rain-bursts produced $114.8 \mathrm{~mm}$ of accumulated precipitation, an impressive amount for $6 \mathrm{~h}$-duration in Funchal, as it was confirmed after a comparison with previous corresponding annual maxima over the 1980-2009 period: This value exceeds the previous maximum for this time length $(92.6 \mathrm{~mm}$, observed in 27 September 1989).

\section{Synoptic context}

This section is devoted to the discussion of the main aspects of the atmospheric circulation and associated physical mechanisms that were responsible for the 20 February copious amounts of rainfall in Madeira Island. It is important to address first the large-scale atmospheric conditions associated with the prolonged precipitation anomaly in Madeira during the winter 2010. In fact, this winter was characterised by a clear prevalence of the negative phase of the North Atlantic Oscillation (NAO) (new winter record-breaking, e.g., Osborn, 2011), with strong positive SLP anomalies in the Iceland low area and negative anomalies in the Azores high pressure region (Andrade et al., 2011; Vicente-Serrano et al., 2011). In previous works (e.g., Ulbrich et al., 1999; Trigo et al., 2004; Santos et al., 2005, 2009) it was demonstrated that these large-scale atmospheric circulation conditions associated with negative NAO phases induce an increase in the frequency of mid-latitude cyclones affecting the entire western Iberian region and a large sector of the contiguous north Atlantic basin, therefore, affecting also the island of Madeira. This significant increase (decrease) of low pressure systems during the negative (positive) phase of the NAO pattern is the most important mechanism contributing for high (low) precipitation amounts over western Iberia (Ulbrich et al., 1999; 

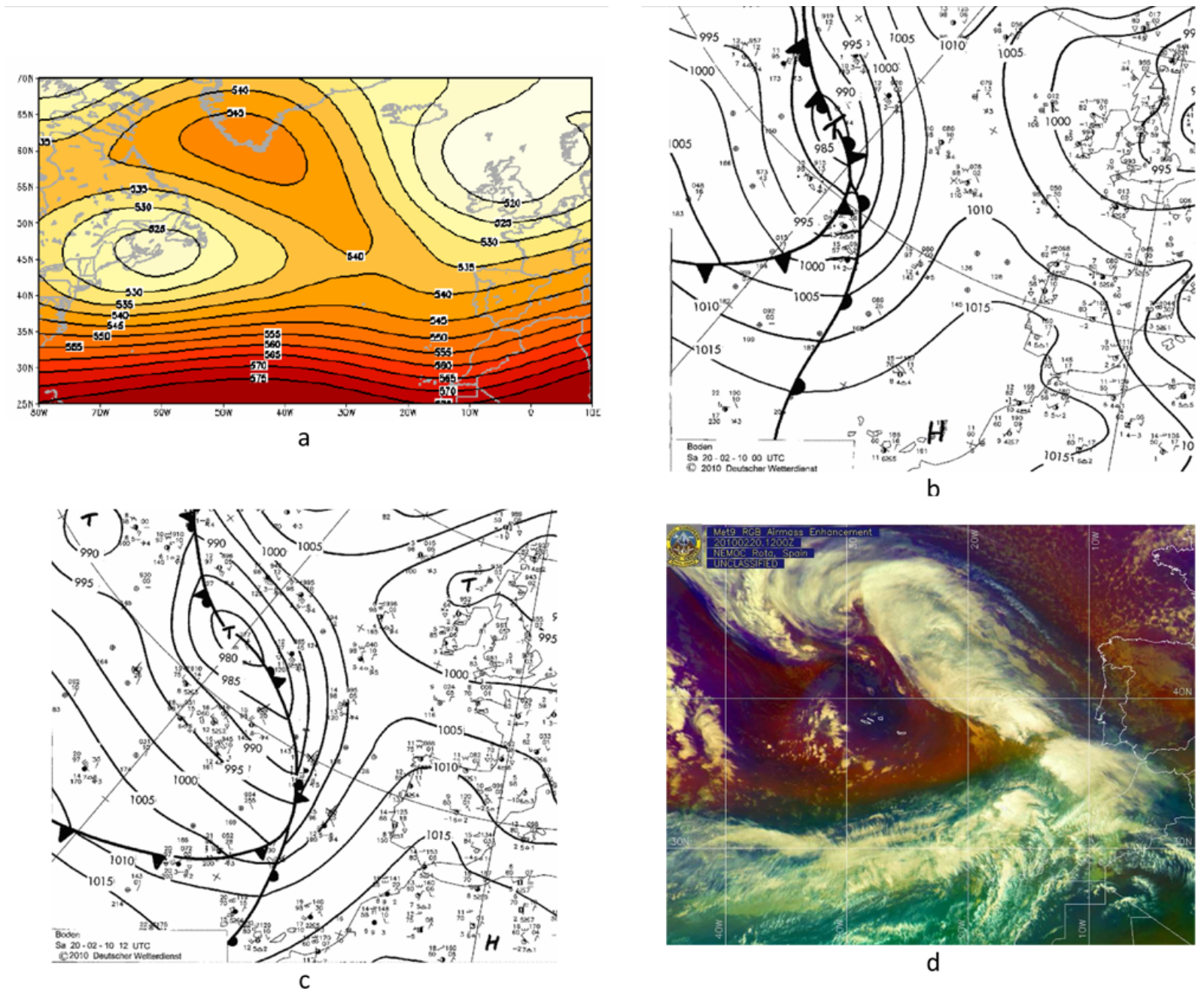

Fig. 6. (a) Geopotential height field $500 \mathrm{hPa}$ for 15-21 February 2010; (b) surface chart 20 February 2010, 00:00 UTC (c) same as (b) but for 12:00 UTC (d) Met9 satellite figure, 12:00 UTC. Sources: (a) Era-interim (b-c) DWD (d) Naval European Meteorology and Oceanographic Center (https://www.nemoc.navy.mil/site/satellite/).

Trigo et al., 2004). This relationship was, once again, confirmed during the 2010 winter, which was a very wet winter in Portugal (Andrade et al., 2011), southern Spain (VicenteSerrano et al., 2011) and Madeira (Fig. 3a). Therefore, these prevailing large-scale atmospheric circulation conditions had a preponderant role by promoting higher frequency of synoptic disturbances over the region and contributing for the anomalous wet winter 2010 in Madeira, as it was demonstrated in detail in Sect. 3.1.

On the third week of February 2010, the large-scale atmospheric circulation over the North Atlantic was dominated by a diffluent block of the mid-latitude circulation, with a high pressure centre over Southern Greenland and a cyclonic cell located close to Newfoundland and extending west almost to the Azores islands (Fig. 6a). This configuration is associated with a southward shift of the Westerlies, along the $30-35^{\circ} \mathrm{N}$ latitudinal band, therefore, directed towards the Madeira region. The large-scale circulation conditions for this week are similar to those found predominantly during the winter 2010 (Andrade et al., 2011; Vicente-Serrano et al., 2011), with SLP anomalies showing a clear north-south oriented dipole, with strong positive (negative) anomalies located over the Iceland/Greenland (Azores) region.

On 20 February, 00:00 UTC, a deep cyclone was located around $30^{\circ} \mathrm{W}, 45^{\circ} \mathrm{N}$, near the Azores, with its fronts extending to the subtropics (Fig. 6b). While the cyclone remains almost stationary, its associated fronts move eastwards during the day, and are located close to Madeira in the early afternoon (cf. situation for 12:00 UTC on Fig. 6c). The approximation of the frontal system was responsible for a rapid and outstanding change on the atmospheric conditions over the region, and as is visible in the Fig. 6b, c and d, the island was closely affected by the occlusion region (frontal triple point), where massive convective cloudiness (Fig. 6d) was produced. 

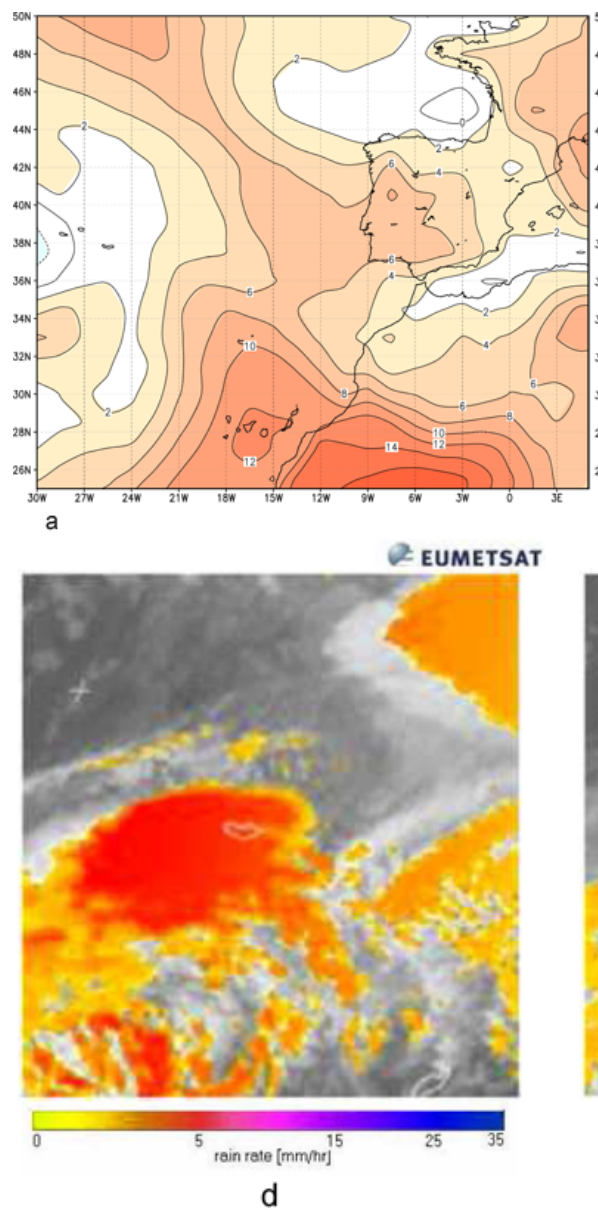
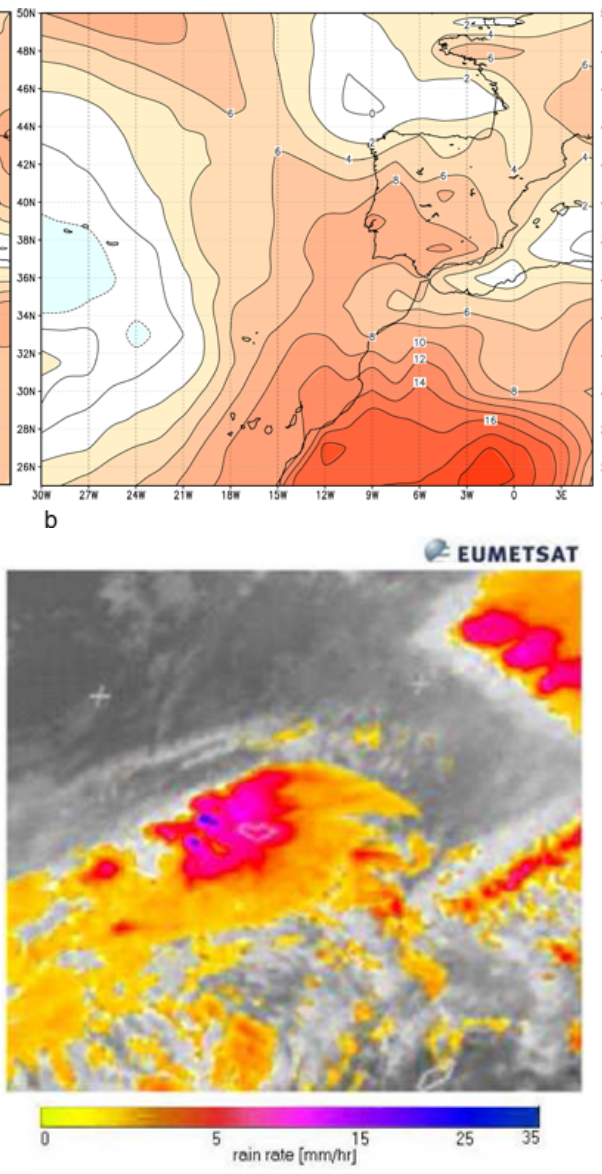

e
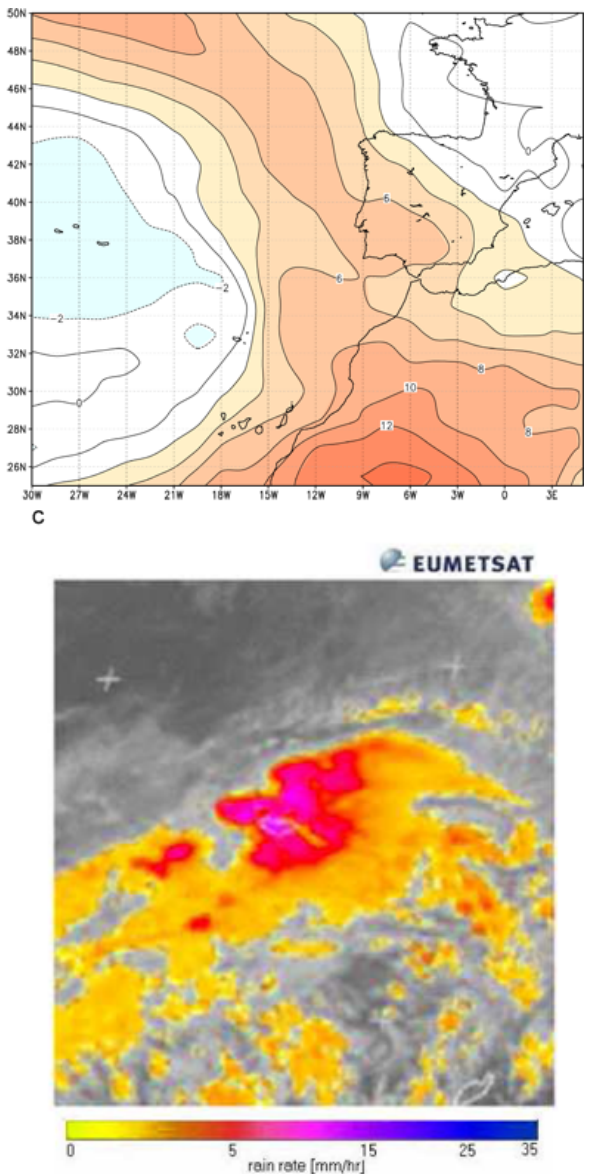

$f$

Fig. 7. Thermodynamic instability and mesoscale precipitation systems over the Madeira Atlantic sector: (a-c) Lifted index distribution over the Madeira Atlantic sector at 00:00, 06:00 and 12:00 UTC (units in ${ }^{\circ} \mathrm{C}$, source: ERA-Interim reanalysis, ECWMF); (d-f) Multi-Sensor Precipitation Estimate (MPE) product images at 09:45, 11:15 and 11:45 UTC (units in $\mathrm{mm} \mathrm{h}^{-1}$, source EUMETSAT). The colours scale of the MPE images was modified in order to enhance the visibility of the island contours.

The thermodynamic environment that promoted such severe convective activity may be analysed more appropriately through the evolution of instability parameters distribution, such as Lifted index (LI) and CAPE (Convective Available Potential Energy), both extracted from ERA-Interim reanalysis dataset. Figure $7 \mathrm{a}-\mathrm{c}$ shows that the arrival of the frontal system occurred under an unstable troposphere, with a core of very unstable conditions (delimited by the $-2{ }^{\circ} \mathrm{C}$ isoline) located close to the island by the late morning of the 20 February 2010. Despite this presence of high thermodynamic instability, demonstrated by the LI data evolution over the region (Fig. 7a-c), the storm activity had developed with low to moderate values of CAPE, showing that the highest spots that crossed the region achieved amounts around $300 \mathrm{~J} \mathrm{~kg}^{-1}$ (not shown).

This thermodynamic analysis can also be complemented using the radiosonde measurements from Funchal: Fig. 8 compares the situation on 19 February 2010 - the day before the rainstorm (blue lines) - with the 20 February sounding (red lines; both soundings launched at 12:00 UTC). On 19 February, the Funchal area was affected by anticyclonic conditions, with weak winds in the lower part of the air column. The approximation of the frontal area produced a dramatic change of the atmospheric conditions: the winds intensified and turned west at the upper levels and southwest at the lower levels. This wind speed increase was very strong at the lower levels. The air temperature rose significantly throughout the entire column, especially at the lower troposphere (up to $10^{\circ} \mathrm{C}$ ), while the humidity profile changed significantly, being almost saturated below $750 \mathrm{hPa}$. Such changes resulted in an increase of precipitable water (PW) from $13.4 \mathrm{~mm}$ to $37.0 \mathrm{~mm}$, showing that the water vapour availability remained almost three times higher, even when the rainstorm was in progress, and after $5 / 6 \mathrm{~h}$ of intense rainfall.

The absence of a meteorological radar in Madeira, which could allow a suitable mesoscale analysis of this extreme event, is a relevant constraint. Nevertheless, this limitation 


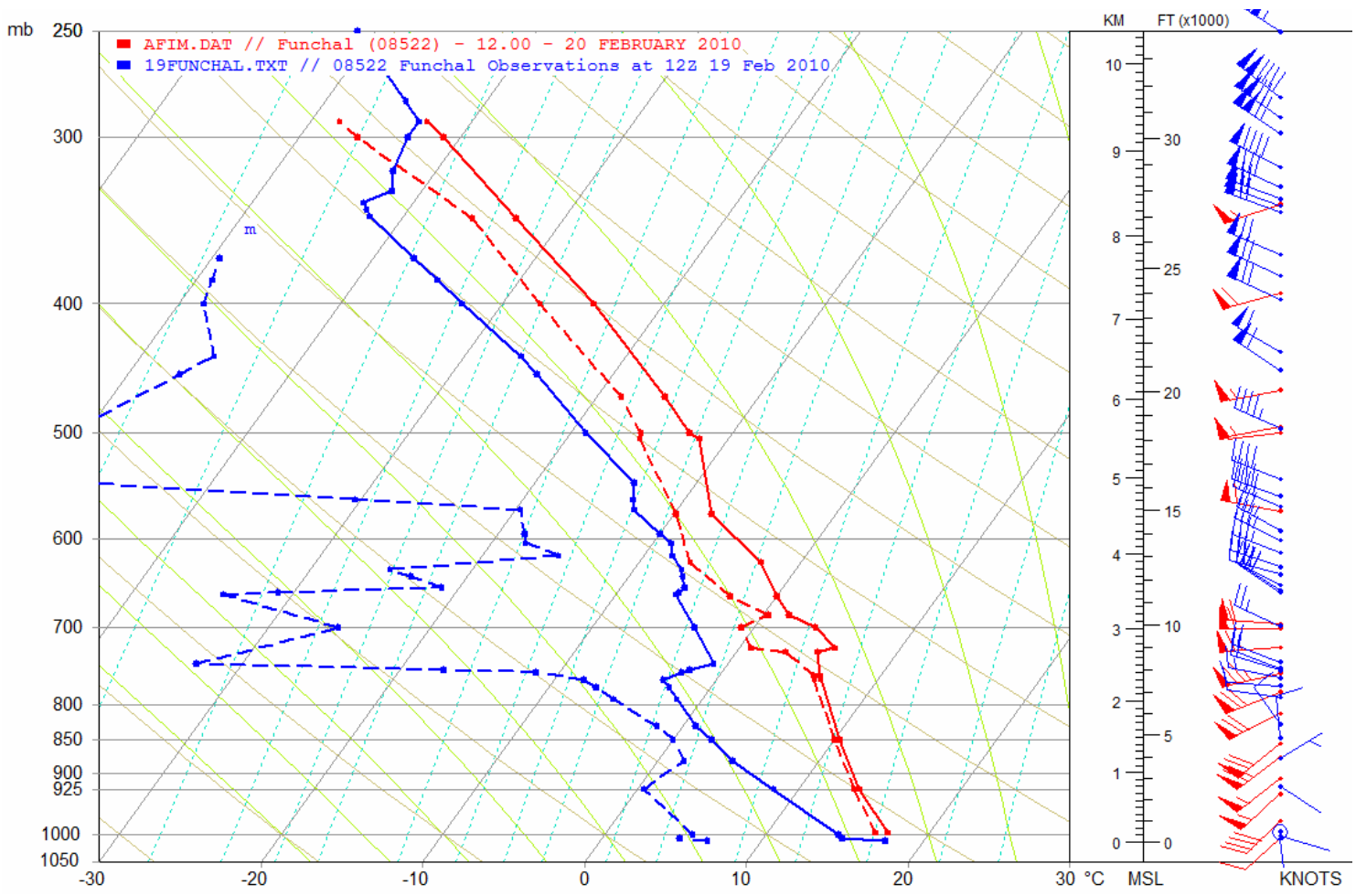

Fig. 8. Projection on a skew-T diagram of the 19 February 2010 (12:00 UTC) sounding in Funchal (blue symbols) and in 20 February 2010 (also at 12:00 UTC, in red symbols).

was partially overcome by analysing the sequence of multisensor precipitation estimate (MPE) images, a product based on an algorithm that combines polar orbital microwave measurements and Meteosat IR channels, very useful for applications in areas with poor or no radar coverage and available at EUMETSAT with a temporal resolution of $15 \mathrm{~min}$. The analysis of the complete sequence of MPE images (not shown here) allows us to confirm that several mesoscale precipitation systems crossed Madeira moving from West/Southwest to East/Northeast, therefore, affecting primarily the southern flanks of the island, as it was presumed in Sect. 3.2. The most long-lived and active of these mesoscale convective cloud systems moved over the island between 09:45 and 11:45 (Fig. 7d-f), a quasi-stationary precipitation system that was responsible for the most critical phase of the storm. Moreover, the observed increase of convective activity when this massive cloud system (Fig. 7) overtopped the island, suggests that the orography probably contributed to trigger and/or reinforce the dynamical uplifts. This assessment is in line with results of the modelling study by Luna et al. (2011), who documented the importance of the orographic forcing to this event. Therefore, orographic effects will not be further addressed in the present study.

At this stage, two key questions are important to understand the unusual high levels of moisture availability and tropospheric instability, namely we must (1) evaluate the dynamical conditions that promoted such anomalous humidity availability over Madeira region on 20 February 2010, and (2) identify the uplift mechanism that induced deep convection activity. To achieve this goal we have analysed the upper-air wind speed and divergence (both at jet stream level, the $250 \mathrm{hPa}$ pressure level) for the 20 February (Fig. 9, left panels). On 20 February, 00:00 UTC, the upper-air jet stream is located over the Eastern Atlantic, between 30 and $35^{\circ} \mathrm{N}$. At 06:00 UTC, the Madeira region is placed under the northward jet exit zone, where strong upper air divergence, indicative of strong uplifting, is observed. This fact supports the hypothesis that large scale forcing was crucial to the occurrence of the event. While the area with strongest upper air divergence moves further east in the following hours, the area within Madeira remained largely with favourably large-scale conditions for large-scale vertical movements.

Simultaneously, the evolution at lower levels also contributed to deep convection triggering. The $850 \mathrm{hPa}$ wind speed fields (Fig. 9, right panels) exhibit strong low-level southwesterlies (up to $30 \mathrm{~m} \mathrm{~s}^{-1}$ ) over the region, and it must be noted that this pressure level approximately corresponds to the uplands heights of the island. This circulation prompted the advection of a strong humidity plume with a southwest-northeast orientation (Fig. 9b), contained within the warm section of the cyclone, most probably transported within a tropical air mass (see greenish areas over the 

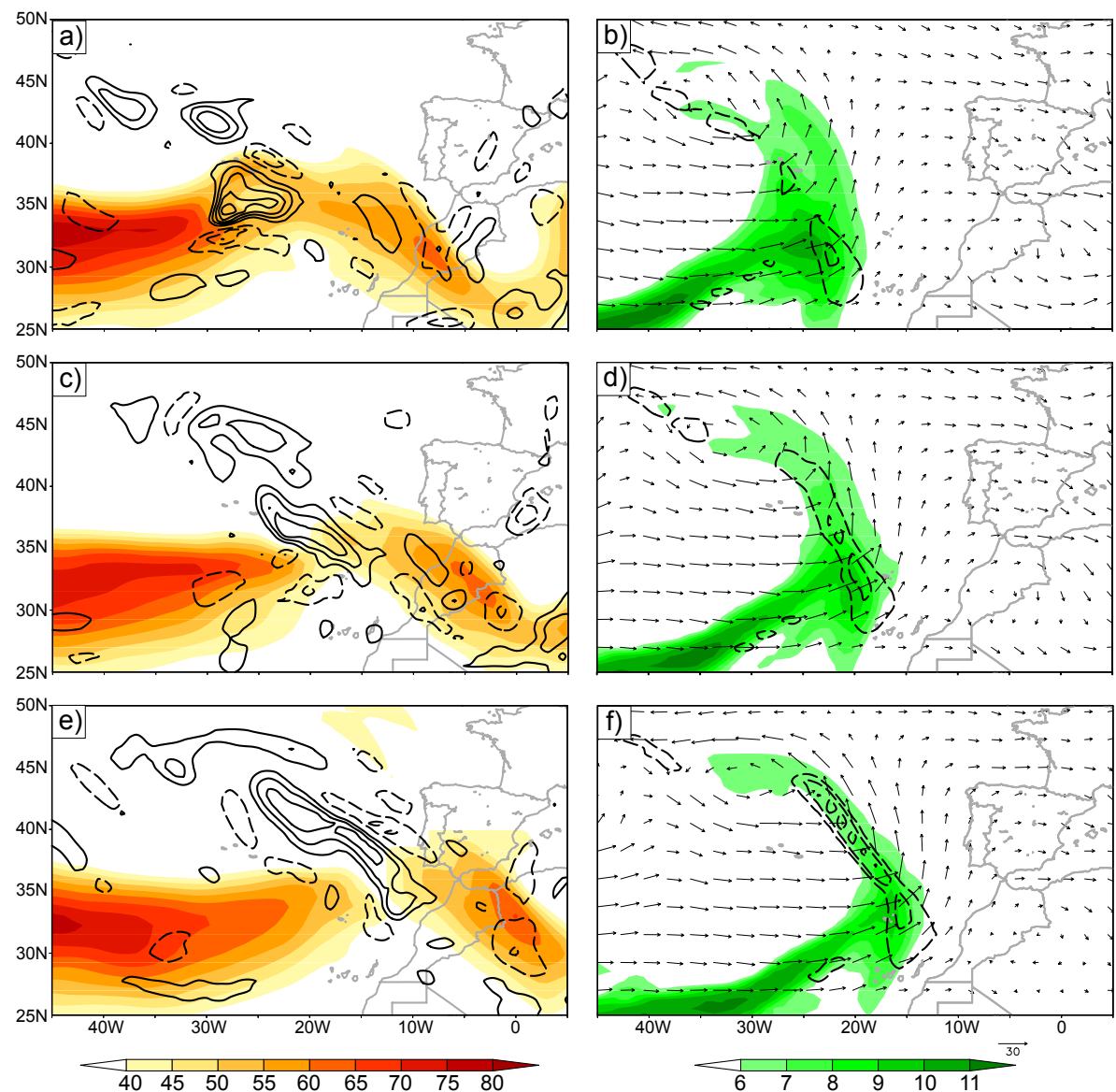

Fig. 9. (a) Wind speed (colours, units in $\mathrm{m} \mathrm{s}^{-1}$ ) and divergence at $250 \mathrm{hPa}$ geopotential level (solid lines with contours every $2 \times 10^{-5} \mathrm{~s}^{-1}$, zero line removed), for 20 February 2010, 00:00 UTC; (b) wind speed (arrows, units in $\mathrm{m} \mathrm{s}^{-1}$ ), specific moisture content (colours, units in $10^{-3} \mathrm{~kg} \mathrm{~kg}^{-1}$ ) and moisture convergence (dashed lines with contours every $10^{-5} \mathrm{~kg} \mathrm{~m}^{-2} \mathrm{~s}-1$, zero line removed, only negative values are shown) at 850 hPa geopotential level for 00:00 UTC; (c) as (a) but for 06:00 UTC; (d) as (b) but for 06:00 UTC; (e) as (a) but for 12:00 UTC; (f) as (b) but for 12:00 UTC.

Eastern Atlantic in Fig. 6d). Therefore, this impressive humidity surplus, illustrated by the specific humidity at $850 \mathrm{hPa}$ geopotential level (Fig. 9b), arrived in the Madeira region at the exact moment when other favourable dynamical mechanisms for deep convection were already ongoing, e.g., upper level divergence and frontal uplift (Fig. 9 left). Figure 9 also depicts low level moisture convergence, a good indicator for large-scale precipitation, indicating that Madeira was under good large-scale conditions between 06:00 UTC and the early afternoon. Around midday, the occlusion point of the frontal system was located close to Madeira, which additionally strengthened the precipitation.

To investigate the source of the air mass and moisture associated with the 20 February storm in the Madeira region, backward trajectories over three days were computed starting from this location, at $850 \mathrm{hPa}$ and $700 \mathrm{hPa}$ pressure levels (Fig 10a and b). During the initial phase of the storm (06:00 UTC, Fig. 10a), the source region is different from the $850 \mathrm{hPa}$ and $700 \mathrm{hPa}$ levels, originating respectively, from the central Atlantic region $\left(40^{\circ} \mathrm{N}\right)$ and central subtropical Atlantic $\left(25-27^{\circ} \mathrm{N}\right)$ at lower levels. While the latter shows large amounts of moisture during the last $48 \mathrm{~h}$, the former only picks up moisture in large quantities shortly before arriving over Madeira. Interestingly, the trajectories at 12:00 UTC (i.e., during the most intense precipitation period) all arrive from the subtropics (between 20 and $25^{\circ} \mathrm{N}$ ) for both levels. The trajectories are longer, in some cases tracing back to the Caribbean. Therefore, it is plausible to argue that the moisture brought along these trajectories contributed to reinforce the moisture availability within the warm sector of the cyclone, which then largely precipitated over the Madeira region.

Finally, it must be stressed that all the above described dynamical features converged close to the Madeira mountainous island. Additionally, Madeira's pronounced orography worked as an amplifying factor for precipitation generation. Therefore, all the mentioned ingredients - e.g., upper air divergence, jet stream relative position, heat and moisture 

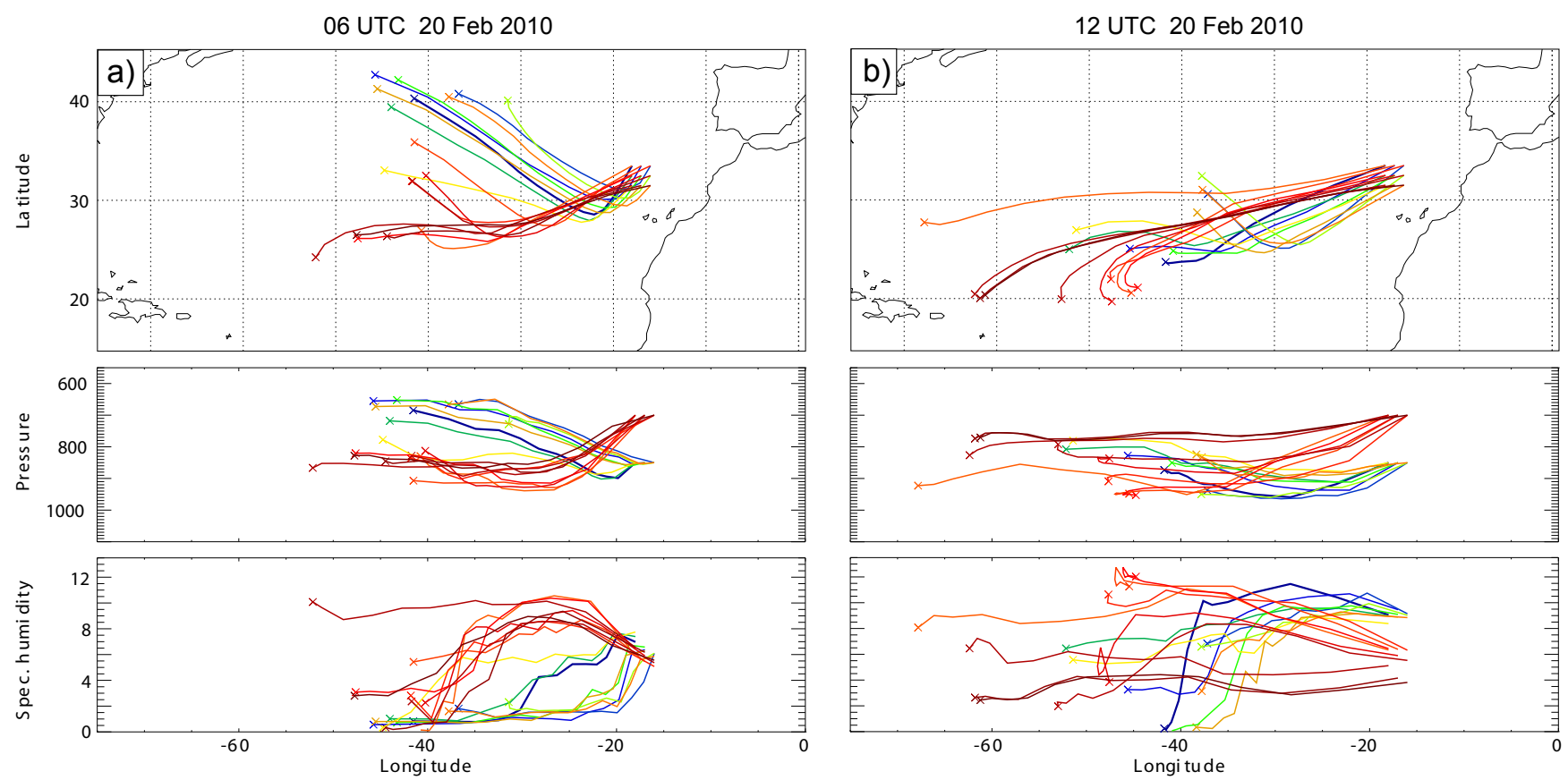

Fig. 10. Backward trajectories over $72 \mathrm{~h}$ based on Era-interim data. Trajectories are started over and near Madeira in $850 \mathrm{hPa}$ and $700 \mathrm{hPa}$ on 20 February 2010 at (a) 06:00 UTC (b) 12:00 UTC. Shown are the horizontal paths (upper panel), the associated pressure level (middle panel; unit: hPa) and the associated humidity (lower panel, unit: $10^{-3} \mathrm{~kg} \mathrm{~kg}^{-1}$ ) during each step of the trajectory.

availability - were probably sufficient conditions to explain this strong storm occurrence in the Madeira archipelago. Nevertheless, its anomalous duration and intensity was certainly aggravated by the orographic controls, responsible for uplifts triggering its reinforcement and temporal persistence. The southern flanks of the Madeira mountains, especially those that surround the Funchal city district, were more exposed to the dominant southwesterly humid fluxes associated with this event, which can be important to understand the location of the most intense cores of produced precipitation and, subsequently, the distribution of the numerous and disastrous flash-flood impacts.

\section{Discussion and conclusions}

The 20 February Madeira flash-floods were investigated with regard to the synoptic/large-scale meteorological context focusing on the dynamical controls of the event. The disaster was preceded by anomalous wet conditions over the 2010 winter - responsible for record-breaking values of monthly and seasonal values of winter accumulated precipitation and also being characterised by the occurrence of several intense rainfall episodes affecting the island (e.g., 22 December 2009, 2 February 2010). This accumulated precipitation was extremely important for the catastrophic impacts of the 20 February 2010 event, triggering thousands of landslides. Despite the magnitude of the earlier extreme precipitation episodes (22 December 2009 and 2 February 2010, both with daily precipitation amounts above $200 \mathrm{~mm}$ at the Funchal mountains), those events have not triggered such devastating flash-floods, landslides and debris flows. Therefore, the anomalous wet 2010 winter in Madeira was a concurrent factor to explain the severity of the 20 February flash-floods and their associated impacts.

Large-scale atmospheric forcings were crucial to induce favourable conditions for the occurrence of deep convection close to Madeira in 20 February 2010. When a frontal cyclone moving eastwards reached the region, its activity was enhanced. One factor was observed; strong upper-air divergence connected to the northward upper-air jet exit zone and indicating the occurrence of strong uplifts. In conjunction, it was also demonstrated that strong humidity convergence at lower levels (at and below $700 \mathrm{hPa}$ ) was another important dynamical ingredient that, most likely, contributed to enhancing upward movements and higher precipitation generation. These dynamical mechanisms resulted in strong cyclonic activity within the cyclone system that affected Madeira by its occlusion point, during the morning of 20 February, coinciding with the most critical period of rainstorm. Besides these dynamical conditions associated with the synoptic situation, it also stressed upon the role of orographic controls on the uplifts (cf. Luna et al., 2011), contributing to increasing the accumulated rainfall over the southern flanks of Madeira. Our study provides evidence that also large-scale forcing and pre-existing in situ conditions (total rainfall in previous winters) were very important factors for the extraordinary magnitude of the event. 
The daily and sub-daily precipitation records associated with 20 February flash-floods in Madeira were analysed in detail. The sustained rain-bursts produced two main cores of extremely abundant precipitation, with amounts varying between 250 and $370 \mathrm{~mm}$, one located over the uplands and the southern slopes of the eastern mountains (Areeiro plateau) and another one centred over the central plateau sector (Paúl da Serra and Encumeada). This assessment may be useful in order to evaluate and to understand the geographic incidence of the storm impacts, like the triggered landslides distribution, an investigation that should be addressed by geomorphologists and other specialists. The exceptionality of the 20 February 2010 event was also investigated by estimating the return periods of $24 \mathrm{~h}$ rainfall for the available meteorological stations with appropriate long time series. The results clearly suggest that the event was much more exceptional in the Funchal area than in the uplands, in spite of the higher total accumulated precipitation over the central and eastern mountains.

The control of rainfall on landslides differs substantially depending upon landslide depth and kinematics and the affected material. Shallow soil slips and rapid debris flows are typically activated by short period of very intense rain while deep-seated rotational and translational slides are usually associated with less intense rainfall occurring in period lasting from several weeks to several months (Van Asch et al., 1999). It is interesting to notice that the vast number of landslide occurrences in southern Madeira fit well with two rainfall triggering mechanisms described in previous works in relation to landslides close to Lisbon (Trigo et al., 2005; Zêzere et al., 2005) and in the Azores archipelago (Marques et al., 2009). In fact, using empirical relationships between rainfall intensity and slope instability, it has been shown that critical rainfall conditions for failure are not the same for different types of landslides (Trigo et al., 2005). A considerable fraction of landslide events occurred immediately after intensive short bursts (1-5 days) of precipitation while another group of landslide events took place after prolonged periods (3090 days) of successive precipitation episodes of moderate intensity (Zêzere et al., 2005). Low frequency atmospheric patterns are associated with anomalous precipitation at the seasonal scale and in recent years it has been found as a significant impact exerted by North Atlantic Oscillation (NAO) on the Portuguese mainland winter precipitation (Trigo et al., 2004) and over the recent landslide activity in the study area (Trigo et al., 2005; Zêzere et al., 2005). This link is related to the control that the NAO exerts, at the monthly and seasonal scales, on the storms entering from the North Atlantic Ocean and corresponding precipitation field. However, note that the NAO is the dominant, but not the only relevant largescale pattern affecting precipitation in this area: for example, Santos et al. (2005) documented the relevance of the East Atlantic pattern in this context.

In summary, the large number of landslide events observed on the 20 February 2010 (Fig. 5b) resulted from two mechanisms working at different temporal scales, namely: (1) the strongly negative NAO phase throughout the winter that was responsible for the record rainy season observed and (2) the outstanding amounts of precipitation observed on a daily and hourly scale during the event, particularly in the mid and upper slopes of the mountains with drainage basins in the southern flanks.

The very harmful and deadly impacts of the 20 February 2010 storm in Madeira were the consequence of a complex conjunction of environmental and societal factors. This work focused on the meteorological component of the flashfloods, but the impacts of this complex natural disaster were undoubtedly aggravated by several other physical conditions (e.g., geomorphological conditions, effects from costal surge) as also by anthropic factors, taking into account the strong human occupation of some of the most affected areas.

Acknowledgements. This work was supported by the Portuguese Foundation for Science and Technology (FCT) through project Disaster - GIS database on hydro-geomorphologic disasters in Portugal: a tool for environmental management and emergency planning (PTDC/CS-GEO/ 103231/2008).

This article also results from the research performed in 2010 for the Secretaria Regional do Equipamento Social da Região Autónoma da Madeira, entitled "Estudo de Avaliação do Risco de Aluviões da Ilha da Madeira", and carried out by a consortium formed by the Instituto Superior Técnico (IST, Portugal), the Universidade da Madeira (Madeira University) and the Laboratório Regional de Engenharia Civil (LREC).

The authors are grateful to Victor Prior (Instituto de Meteorologia, Portugal), for the kind availability of the radiosoundings from the Funchal station and to Dominique Yuen (Univ. Cologne) for help with Figs. 9 and 10.

Edited by: A. Mugnai

Reviewed by: M. C. Llasat and another anonymous referee

\section{References}

Alexandersson, H., Førland, E. J., Helminen, J., Sjöblom, N., and Tveito, O. E.: Extreme value analysis in the Nordic countries pilot studies of minimum temperature and maximum daily precipitation and a review of methods in use, DNMI, Report No. 03/01 KLIMA, Norwegian Meteorological Institute, Oslo, 2001.

Andrade, C., Santos, J. A., Pinto, J. G., and Corte-Real, J.: Largescale atmospheric dynamics of the wet winter 2009-2010 and its impact on hydrology in Portugal, Clim. Res., 46, 29-41, 2011.

Ball, S.: Exceptional rainfall in Gibraltar during winter 2009/2010, Weather, 66, 22-25, 2011.

Coles, S.: An Introduction to Statistical Modelling of Extreme Values, Springer, London, 208 pp., 2001.

Doswell III, C. A. and Rasmussen, E. N.: The effect of neglecting the virtual temperature correction on CAPE calculations, Weather Forecast., 9, 625-629, 1994.

EM-DAT CRED: EM-SAT: The OFDA/CRED International Disaster Database, Université Catholique de Louvain, Brussels (Bel- 
gium), available at: www.emdat.be (last access: 8 March 2012), 2010.

Galway, J. G.: The lifted index as a predictor of latent instability, B. Am. Meteorol. Soc., 37, 528-529, 1956.

Goovaerts, P.: Geostatistics for Natural Resources Evaluation, Oxford University Press, New York, 1997.

Gumbel, E. J.: Statistics of Extremes, Columbia University Press, 1958.

Llasat, M. C., Rigo, T., and Barriendos, M.: The "Montserrat2000"flash-flood event: a comparison with the floods that have occurred in the north-eastern Iberian peninsula since the 14th century, Int. J. Climatol., 23, 453-469, 2003.

Luna, T., Rocha, A., Carvalho, A. C., Ferreira, J. A., and Sousa, J.: Modelling the extreme precipitation event over Madeira Island on 20 February 2010, Nat. Hazards Earth Syst. Sci., 11, 24372452, doi:10.5194/nhess-11-2437-2011, 2011.

Marques, R., Zêzere, J. L., Trigo, R. M., Gaspar, J. L., and Trigo, I. F.: Rainfall patterns and critical values associated with landslides in Povoação County (São Miguel Island, Azores): relationships with the North Atlantic Oscillation), Hydrol. Process., 22, 478494, 2008

Methven, J.: Offline trajectories: Calculation and accuracy, UK.Univ. Global Atmos. Modelling Programme, Dept. of Meteorol., Univ. of Reading, Reading, UK, Tech. Report 44, 18 pp., 1997.

Methven, J., Evans, M., Simmonds, P., and Spain, G.: Estimating relationships between air-mass origin and chemical composition, J. Geophys. Res., 106, 5005-5019, 2001.

Milelli, M., Llasat, M. C., and Ducrocq, V.: The cases of June 2000, November 2002 and September 2002 as examples of Mediterranean floods, Nat. Hazards Earth Syst. Sci., 6, 271-284, doi:10.5194/nhess-6-271-2006, 2006.

Moncrieff, M. W. and Green, J. S. A.: The propagation of steady convective overturning in shear, Q. J. Roy. Meteor. Soc., 98, 336352, 1972.

Osborn, T. J.: Winter 2009/2010 temperatures and a recordbreaking North Atlantic Oscillation Index, Weather, 66, 19-21, 2011.

Prada, S., Sequeira, M. M., Figueira, C., and Silva, M. O.: Fog precipitation and rainfall interception in the natural forests of Madeira Island (Portugal), Agr. Forest Meteorol., 149, 11791187, 2009.

Quintal, R.: Aluviões da Madeira. Séculos XIX e XX, Territorium, Revista de Geografia Física aplicada ao Ordenamento do Território e Gestão de Riscos Naturais, Minerva, Coimbra, 6, 31-48, 1999.

Rigo, T. and Llasat, M. C.: Radar analysis of the life cycle of Mesoscale Convective Systems during the 10 June 2000 event, Nat. Hazards Earth Syst. Sci., 5, 959-970, doi:10.5194/nhess-5959-2005, 2005.
Ribeiro, O.: A Ilha da Madeira até meados do Séc, XX, Estudo Geográfico, Instituto de Cultura e Língua Portuguesa, 1985.

Rodrigues, D. and Ayala-Carcedo, F. J.: Rain-induced landslides and debris flows in Madeira Island. Landslide News, J. Jpn. Landslide Soc. 14, 43-45, 2003.

Santos, J. A., Corte-Real, J., and Leite, S. M.: Weather regimes and their connection to the winter rainfall in Portugal, Int. J. Climatol., 25, 33-50, 2005.

Santos, J. A., Andrade, C., Corte-Real, J., and Leite, S.: The role of large-scale eddies in the occurrence of winter precipitation deficits in Portugal, Int. J. Climatol., 29, 1493-1507, 2009.

SRES: Estudo de Avaliação do Risco de Aluviões da Ilha da Madeira - Relatório Síntese, Instituto Superior Técnico, a Universidade da Madeira e o Laboratório Regional de Engenharia Civil, 2010.

Shewchuk, J.: RAOB (the Rawinsonde Observation Program) for Windows. Version 5.1, Environmental Research Services, available from Environmental Research Services, 1134 Delaware Dr. Matamoras, PA 18336, 2002.

Showalter, P. S. and Lu, Y. (Eds.): Geospatial Techniques in Urban Hazard and Disaster Analysis. Geotechnologies and the Environment, Springer, London/New York, 2010.

Storch, H. V. and Zwiers, F. W.: Statistical analysis in climate research, Cambridge University Press, United Kingdom, 2003.

Svenson, C. and Jones, D. A.: Review of rainfall frequency estimation methods, J. Flood Risk Manage., 2, 296-313, 2010.

Trigo, R. M., Pozo-Vasquez, D., Osborn, T. J., Castro-Díez, Y., Gámis-Fortis, S., and Esteban-Parra, M. J.: North Atlantic Oscillation influence on precipitation, river flow and water resources in the Iberian Peninsula, Int. J. Climatol., 24, 925-944, 2004.

Trigo, R. M., Zêzere, J. L., Rodrigues, M. L., and Trigo, I. F.: The influence of the North Atlantic Oscillation on rainfall triggering of landslides near Lisbon, Nat. Hazards, 36, 331-354, 2005.

Ulbrich, U., Christoph, M., Pinto, J. G., and Corte-Real, J.: Dependence of winter precipitation over Portugal on NAO and baroclinic wave activity, Int. J. Climatol., 19, 379-390, 1999.

Van Asch, T., Buma, J., and Van Beek, L.: A view on some hydrological triggering systems in landslides, Geomorphology, 30, 25-32, 1999.

Vicente-Serrano, S., Trigo, R. M., López-Moreno, J., Liberato, M. L. R., Lorenzo-Lacruz, J., Berguría, S., Móran-Tejeda, H., and El Kenawi, A.: Extreme winter precipitation in the Iberian Peninsula in 2010: anomalies, driving mechanisms and future projections, Clim. Res., 46, 51-65, 2011.

Wilks, D.: Statistical methods in atmospheric sciences, Academic Press, 2005.

Zêzere, J. L., Trigo, R. M., and Trigo, I. F.: Shallow and deep landslides induced by rainfall in the Lisbon region (Portugal): assessment of relationships with the North Atlantic Oscillation, Nat. Hazards Earth Syst. Sci., 5, 331-344, doi:10.5194/nhess-5-3312005, 2005. 